\title{
Elemental abundance analyses with Complejo Astronómico El Leoncito REOSC echelle spectrograms ${ }^{\star}$
}

\section{II. $\mu$ Leporis, 7 Sextantis, HR 4817, and 28 Herculis}

\author{
S.J. Adelman ${ }^{1, \star \star}$ and O.I. Pintado ${ }^{2, \star \star \star}$ \\ 1 Departament of Physics, The Citadel, 171 Moultrie Street, Charleston, SC 29409, U.S.A. \\ ${ }^{2}$ Complejo Astronómico El Leoncito, CC 468, 5400 San Juan, Argentina
}

Received October 28, 1996; accepted January 7, 1997

\begin{abstract}
Elemental abundances are derived for four sharp-lined stars, the Mercury-Manganese stars $\mu$ Lep, HR 4817, and 28 Her, and 7 Sex, a Population I star with Population II space motions, using REOSC echelle spectrograms obtained at CASLEO to extend previous studies. Comparisons with published equivalent widths indicate that the CASLEO scale is marginally larger than those of DAO Reticon and KPNO CCD spectra. The CASLEO spectrograms have improved the quality of the abundance determinations. New abundances are found for a few elements.
\end{abstract}

Key words: stars: abundances — stars: chemically peculiar - star: $\mu$ Leporis - stars: HR 4817 - stars: 28 Herculis - stars: 7 Sextantis

\section{Introduction}

This paper presents studies of four sharp-lined B and A stars using spectrograms obtained at the $2.15 \mathrm{~m}$ telescope of the Complejo Astronomico El Leoncito (CASLEO) and a REOSC echelle spectrograph, which is on loan from the Institute d'astrophysique de Liége, Belgium, and a TEK

Send offprint requests to: S.J. Adelman

* Tables 3-6 will be available in electronic form at the CDS via anonymous ftp to cdsarc.u-strasbg.fr (130.79.128.5) or via http://cdsweb.u-strasbg.fr/Abstract.html

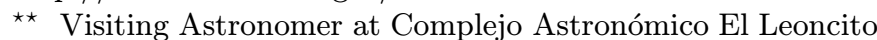
operated under agreement between Consejo Nacional de Investigaciones Científicas y Técnicas de la República Argentina and the National Universities of La Plata, Córdoba and San Juan.

${ }^{\star \star \star}$ Member of Carrera del Invetigador del Consejo Nacional de Investigaciones Científicas y Técnicas de la República Argentina.
1024 CCD. The cross disperser was a grating with 1200 lines $\mathrm{mm}^{-1}$. The resolution is $0.10 \AA \mathrm{pixel}^{-1}$. The spectral reductions were made using IRAF $2.10^{1}$. From bias and flat fields we obtained a combined flat field which was used to divide the stellar spectra to remove the pixelto-pixel variations. The extraction was performed with APALL and the wavelength calibration with IDENTIFY and DISPCOR using the comparison spectra. Additional details are given in Paper I (Pintado \& Adelman 1996).

In that paper comparisons of equivalent widths obtained with the REOSC and other spectrographs indicated that the REOSC equivalent widths were in some cases too large and in other cases too small. To help resolve this issue we selected four stars for which there are well determined equivalent widths in regions with moderate line blending. As we found that $\lambda \lambda 4640-5100$ contained lines of some important atomic species for middle B to early A stars, we also choose stars for which we could extend published studies.

The Mercury-Manganese (HgMn) stars $\mu$ Leporis $(=$ HD $33904=$ HR 1702) and 28 Herculis $(=$ HD 149121 $=$ HR 6158$)$ were most recently analyzed by Adelman (1987) and (1988), respectively. Their apparent rotational velocities are 18 and $8 \mathrm{~km} \mathrm{~s}^{-1}$, respectively. An effective temperature of $12500 \mathrm{~K}$ and surface gravity, $\log g=3.5$, of $\mu$ Lep was derived by comparing spectrophotometry and the $\mathrm{H} \gamma$ profile with the predictions of ATLAS6 (Kurucz 1979) model atmospheres. For $28 \mathrm{Her}$, the values $T_{\text {eff }}=$ $10750 \mathrm{~K}, \log g=3.65$ were found using $u v b y \beta$ photometry and the $\mathrm{H} \gamma$ profile.

The A0 V star 7 Sex (= HD $85504=$ HR 3906) $\left(v \sin i=25 \mathrm{~km} \mathrm{~s}^{-1}\right)$ has nearly solar abundances, but the space motions of a Population II object. The

$1 \quad$ IRAF is distributed by the National Optical Astronomical Observatories which is operated by the Association of Universities for Research in Astronomy, Inc., under a cooperative agreement with the US National Science Foundation. 
recent analysis by Adelman \& Philip (1996) used the homogeneous uvby $\beta$ colors of Hauck \& Mermilliod (1980) with the calibration of Napiwotzki et al. (1993) to find $T_{\text {eff }}=10135 \mathrm{~K}, \log g=3.69$. They compared a Kitt Peak National Observatory (KPNO) CCD spectrogram centered at $\mathrm{H} \gamma$ with the predictions of ATLAS9 solar composition models (Kurucz 1993) by employing SYNTHE (Kurucz \& Avrett 1981) to calculate a $200 \AA$ wide spectral region centered at $4340 \AA$ to confirm the surface gravity.

The HgMn star HR 4817 (= HD 110073) $(v \sin i=$ $23 \mathrm{~km} \mathrm{~s}^{-1}$ ) was most recently studied by Adelman \& Philip (1994). Using photometry as for 7 Sex, these investigators found $T_{\text {eff }}=12900 \mathrm{~K}, \log g=3.72$. In many respects it is similar to the peculiar $\mathrm{HgMn}$ star $53 \mathrm{Tau}$, but it is one of the most He normal members of its class.

For 7 Sex and HR 4817, we could not improve determination of effective temperature and surface gravity. But for $\mu$ Lep and 28 Her $20.4 \AA \mathrm{mm}^{-1}$ DAO Reticon spectrograms containing the $\mathrm{H} \gamma$ profile were obtained. When we compared spectrophotometry and the $\mathrm{H} \gamma$ profile with the predictions of ATLAS9 model atmospheres we found for $\mu$ Lep $T_{\text {eff }}=12400 \mathrm{~K}, \log g=3.80$ for both solar and $+[0.2]$ enhanced models, which are slightly different from those of Adelman (1987). For 28 Her, we used uvby $\beta$ photometry and the calibration of Napiwotzki et al. (1993) to find $T_{\text {eff }}=10906 \mathrm{~K}, \log g=3.86$. As the predicted $\mathrm{H} \gamma$ profile of a $10900 \mathrm{~K}, \log g=3.85$ solar composition ATLAS9 model agreed with the observations, we adopted this model which means 28 Her is slightly hotter and has a slightly greater surface gravity than found by Adelman (1988). Allowing for the differences in helium abundances between the models and the stars (see below), $\log g=3.91$ for $\mu$ Lep and 3.96 for 28 Her.

\section{Reduction of spectrograms}

The stellar lines were identified with the general references A Multiplet Table of Astrophysical Interest (Moore 1945) and Wavelengths and Transition Probabilities for Atoms and Atomic Ions, Part 1 (Reader \& Corliss 1980) as well as the more specialized references P II (Svendenius et al. 1983), P III (Magnusson \& Zetterberg 1987), Mn II (Iglesias \& Velasco 1964), Fe II (Johansson 1978), and Ga II (Isberg \& Litzen 1985). We measured CASLEO spectrograms which cover $4522-5589 \AA$ for $\mu$ Leo, $4450-5057 \AA$ for 7 Sex, $4422-5607 \AA$ for HR 4817, and $4521-5617 \AA$ for 28 Her. Although these spectra extended further into the blue, we did not utilize these regions as they were too heavily line blanketed at our dispersion for equivalent width comparisons.

For 7 Sex, the previous spectroscopic material consisted of $4.7 \AA \mathrm{mm}^{-1}$ KPNO CCD spectrograms covering approximately $3907-3962 \AA, 4118-4168 \AA$, and $4207-4542 \AA$ and a DAO $2.4 \AA \mathrm{mm}^{-1}$ Reticon spectrogram of $4541-4601 \AA$. In the region of overlap
$4450-4601 \AA$, comparison of the equivalent widths of 18 unblended lines yields

$$
W_{\lambda}(\mathrm{CASLEO})=0.9873 W_{\lambda}(\mathrm{DAO} \text { or } \mathrm{KPNO})+3.927
$$

which indicates good agreement except for a minor offset in the zero point.

For $\mu$ Lep, the previous analysis used coadded $2.4 \AA \mathrm{mm}^{-1}$ DAO IIaO spectrograms (9 U plates and $11 \mathrm{~V}$ plates). Comparison of 17 equivalent widths in the $4534-4636 \AA$ region yields

$$
W_{\lambda}(\mathrm{CASLEO})=1.106 W_{\lambda}(\mathrm{DAO})-3.293
$$

and for 28 Her whose previous analysis also used a similar coaddition (14 $\mathrm{U}$ and $20 \mathrm{~V}$ plates), comparison of 20 equivalent widths in the $\lambda \lambda 4522-4639$ region, yields

$$
W_{\lambda}(\mathrm{CASLEO})=1.173 W_{\lambda}(\mathrm{DAO})-2.713,
$$

a result which is in not as good agreement.

For HR 4817, the previous spectroscopic material is $4.7 \AA \mathrm{mm}^{-1} \mathrm{KPNO}$ CCD spectrograms covering approximately $3915-3953 \AA, 4120-4169 \AA, 4218-4269 \AA$, and $4435-4593 \AA$. In the region of overlap $4422-4593 \AA$, comparison of the equivalent widths of 18 lines yields

$$
W_{\lambda}(\mathrm{CASLEO})=1.0098 W_{\lambda}(\mathrm{KPNO})+1.073
$$

in better agreement than for 7 Sex.

Thus the CASLEO equivalent width scale is marginally larger than that based on KPNO CCD and DAO Reticon spectrograms. The discrepancies with the photographic DAO equivalent widths may well reflect problems with the calibration and continuum placement. But please note that only isolated lines which were typically $15 \mathrm{~m} \AA$ and larger were used for the comparison.

Table 1. He/H Values

\begin{tabular}{ccccc}
\hline$\lambda(\AA)$ & $\mu$ Lep & 7 Sex & HR 4817 & 28 Her \\
\hline 4009 & 0.02 & $\ldots$ & $\ldots$ & $\ldots$ \\
4026 & 0.03 & $\ldots$ & $\ldots$ & 0.01 \\
4120 & 0.03 & $\ldots$ & $\ldots$ & $\ldots$ \\
4144 & 0.02 & $\ldots$ & 0.06 & $\ldots$ \\
4388 & 0.04 & 0.10 & $\ldots$ & 0.01 \\
4438 & 0.03 & $\ldots$ & $\ldots$ & 0.01 \\
4472 & 0.02 & 0.12 & 0.04 & 0.02 \\
4713 & 0.02 & 0.11 & 0.04 & 0.01 \\
4921 & 0.02 & 0.08 & $\ldots$ & $\ldots$ \\
& & & & \\
average & 0.03 & 0.10 & 0.05 & 0.01 \\
\hline
\end{tabular}


Table 2. Determination of the microturbulences

\begin{tabular}{|c|c|c|c|c|c|c|c|}
\hline Star & Species & $g f$ values & $n$ & $\begin{array}{l}\xi_{1} \\
\mathrm{~km} / \mathrm{s}\end{array}$ & $\log \mathrm{Fe} / N_{\mathrm{T}}$ & $\begin{array}{l}\xi_{2} \\
\mathrm{~km} / \mathrm{s}\end{array}$ & $\log \mathrm{Fe} / N_{\mathrm{T}}$ \\
\hline 7 Sex & $\begin{array}{l}\text { Fe I } \\
\text { Fe II } \\
\text { adopted }\end{array}$ & $\begin{array}{l}\mathrm{MF}+\mathrm{KX} \\
\mathrm{MF} \\
\mathrm{MF}+\mathrm{KX} \\
\mathrm{MF}\end{array}$ & $\begin{array}{l}51 \\
46 \\
67 \\
37\end{array}$ & $\begin{array}{l}1.7 \\
1.7 \\
1.5 \\
1.8 \\
1.7\end{array}$ & $\begin{array}{l}-4.19 \pm 0.25 \\
-4.22 \pm 0.23 \\
-4.35 \pm 0.26 \\
-4.48 \pm 0.19\end{array}$ & $\begin{array}{l}1.6 \\
1.7 \\
1.4 \\
1.8\end{array}$ & $\begin{array}{l}-4.19 \pm 0.25 \\
-4.22 \pm 0.23 \\
-4.33 \pm 0.26 \\
-4.48 \pm 0.19\end{array}$ \\
\hline$\mu$ Lep & $\begin{array}{l}\text { Fe II } \\
\text { adopted }\end{array}$ & $\begin{array}{l}\mathrm{MF}+\mathrm{KX} \\
\mathrm{MF}\end{array}$ & $\begin{array}{r}107 \\
44\end{array}$ & $\begin{array}{l}0.2 \\
0.3 \\
0.3\end{array}$ & $\begin{array}{l}-4.60 \pm 0.24 \\
-4.67 \pm 0.25\end{array}$ & $\begin{array}{l}0.4 \\
0.4\end{array}$ & $\begin{array}{l}-4.61 \pm 0.23 \\
-4.68 \pm 0.28\end{array}$ \\
\hline HR 4817 & $\begin{array}{l}\text { Fe II } \\
\text { adopted }\end{array}$ & $\begin{array}{l}\mathrm{MF}+\mathrm{KX} \\
\mathrm{MF}\end{array}$ & $\begin{array}{l}65 \\
25\end{array}$ & $\begin{array}{l}0.0 \\
0.0 \\
0.0\end{array}$ & $\begin{array}{l}-4.85 \pm 0.27 \\
-4.94 \pm 0.23\end{array}$ & $\begin{array}{l}0.0 \\
0.0\end{array}$ & $\begin{array}{l}-4.85 \pm 0.27 \\
-4.94 \pm 0.23\end{array}$ \\
\hline 28 Her & $\begin{array}{l}\text { Fe I } \\
\text { Fe II } \\
\text { adopted }\end{array}$ & $\begin{array}{l}\mathrm{MF}+\mathrm{KX} \\
\mathrm{MF}+\mathrm{KX} \\
\mathrm{MF}\end{array}$ & $\begin{array}{r}90 \\
83 \\
223 \\
56\end{array}$ & $\begin{array}{l}0.0 \\
0.0 \\
0.2 \\
0.5 \\
0.2\end{array}$ & $\begin{array}{l}-4.37 \pm 0.31 \\
-4.38 \pm 0.32 \\
-4.35 \pm 0.22 \\
-4.40 \pm 0.20\end{array}$ & $\begin{array}{l}0.0 \\
0.0 \\
0.0 \\
0.5\end{array}$ & $\begin{array}{l}-4.37 \pm 0.31 \\
-4.38 \pm 0.32 \\
-4.35 \pm 0.22 \\
-4.40 \pm 0.20\end{array}$ \\
\hline
\end{tabular}

Reference: $\mathrm{MF}=$ Fuhr et al. (1988).

KX $=$ Kurucz (1993).

\section{The elemental abundance analyses}

We used programs SYNSPEC (Hubeny et al. 1994) and WIDTH9 (Kurucz, private communication, respectively, to determine the helium and metal abundances. The adopted metal-line damping constants were the default semi-classical approximations, except for iron-peak element lines, whose values were based on the data of Kurucz (1993). We applied a 3\% scattered light correction to account for light scattered along the direction of the dispersion, which is an appropriate value for clean optical systems (Gulliver et al. 1996).

Table 1 contains both the derived $\mathrm{He} / \mathrm{H}$ ratios from lines on the CASLEO spectrograms ( $\lambda 4713$ and $\lambda 4921)$ and the older modern spectroscopic material. The slight changes in the effective temperature and surface gravity help increase the $\mathrm{He} / \mathrm{H}$ ratio of $\mu$ Lep. The values derived from the CASLEO equivalent widths for this star are slightly less than those from the DAO equivalent widths. The CASLEO values make 7 Sex appear to be slightly more solar-like. The $\lambda 4713$ values confirm the relatively high $\mathrm{He} / \mathrm{H}$ ratio for the $\mathrm{HgMn}$ star HR 4817 and the relatively low $\mathrm{He} / \mathrm{H}$ ratio for $28 \mathrm{Her}$.

Table 2 summarizes the determination of the microturbulence using Fe I and Fe II lines. The derived abundances are independent of the equivalent width $\left(\xi_{1}\right)$ and result in a minimum scatter about the mean $\left(\xi_{2}\right)$. For $\mu$ Lep and $28 \mathrm{Her}$, we find microturbulences of 0.3 and $0.2 \mathrm{~km} \mathrm{~s}^{-1}$, respectively, rather than zero as previously found for these and most HgMn stars. The use of additional lines makes the values from both species agree better for 7 Sex. For HR 4817, the Fe II lines still indicate no microturbulence. Now there are substantially more lines and a determination can be done just with MF $g f$ values.

Tables 3-6 (which are available only in electronic form) contain the metal line results from our spectra. For each new line, they contain the multiplet number, the wavelength in $\AA$, the equivalent width in $\mathrm{m} \AA$, the $g f$ value and its source, and the derived abundance $\left(\log N / N_{\mathrm{T}}\right)$ where $N_{\mathrm{T}}$ is the total number of atoms per unit volume.

The CASLEO spectrograms for $\mu$ Lep increase the number of lines analyzed relative to Adelman (1987). Of special interest is the detection of $\mathrm{Hg} \mathrm{I}$ (1) 5460.74 whose derived abundance is in excellent agreement with those from $\mathrm{Hg}$ I (1) 4358.34 and $\mathrm{Hg}$ II 3983.96. The slight changes in effective temperature and surface gravity produce minor changes in the abundances by of order 0.1 dex. The agreement between values derived from species of the same element is marginally worse suggesting some further small adjustments in the effective temperature and surface gravity may be required.

For 7 Sex, the CASLEO spectrograms yield new abundances for C I and Y II lines and improved values especially for Mg I, S II, and Mn II lines. Most abundances are slightly closer to solar (Anders \& Grevesse 1989 as updated in Adelman 1996) than the previous study by Adelman \& Philip (1996). The CASLEO values confirm 
Table 7. Comparison of Superficially Normal Star and Solar Abundances (log N/H)

\begin{tabular}{|c|c|c|c|c|c|c|c|c|}
\hline Species & $\kappa$ Cep & $\nu$ Cap & 7 Sex & $\alpha$ Dra & Merak & $\mathrm{o}$ Peg & 21 Lyn & Sun \\
\hline He I & -1.08 & -1.19 & -1.00 & -1.04 & -1.52 & -1.26 & -1.10 & -1.04 \\
\hline C I & -3.78 & $\ldots$ & -2.97 & -3.91 & -3.68 & $\ldots$ & -3.71 & -3.43 \\
\hline C II & -3.62 & -3.39 & -2.81 & -3.51 & -3.76 & -4.40 & $\ldots$ & -3.43 \\
\hline O I & $\ldots$ & -3.33 & -2.94 & -3.49 & $\ldots$ & -3.36 & $\ldots$ & -3.09 \\
\hline $\mathrm{Mg} \mathrm{I}$ & -4.41 & -4.71 & -3.99 & -4.61 & -4.46 & -4.49 & -4.86 & -4.42 \\
\hline $\mathrm{Mg}$ II & -4.55 & -4.61 & -4.27 & -4.86 & -4.59 & -4.54 & -4.79 & -4.42 \\
\hline $\mathrm{Al} \mathrm{I}$ & -5.97 & -6.03 & -5.82 & -6.07 & -5.43 & -5.58 & -6.06 & -5.53 \\
\hline $\mathrm{Al} \mathrm{II}$ & -5.66 & $\ldots$ & $\ldots$ & -5.76 & -5.28 & $\ldots$ & $\ldots$ & -5.53 \\
\hline Si I & $\ldots$ & $\ldots$ & $\ldots$ & $\ldots$ & $\ldots$ & -4.69 & $\ldots$ & -4.45 \\
\hline Si II & -4.56 & -4.69 & -4.40 & -4.89 & -4.49 & -4.43 & -4.53 & -4.45 \\
\hline S II & -4.65 : & -4.85 & -3.99 & -4.60 & $\ldots$ & -4.00 & $\ldots$ & -4.79 \\
\hline Ca I & -5.71 & -5.98 & -5.05 & -6.28 & -5.75 & -5.61 & -6.00 & -5.64 \\
\hline Ca II & -5.41 & -5.55 & -5.24 & -5.61 & -5.28 & -5.43 & -5.66 & -5.64 \\
\hline $\mathrm{Sc} \mathrm{II}$ & -9.20 & -9.34 & -8.64 & -9.41 & -9.20 & -9.30 & -9.39 & -8.90 \\
\hline Ti II & -6.91 & -7.05 & -6.78 & -7.10 & -6.85 & -6.86 & -7.15 & -7.01 \\
\hline V II & -8.03 & -7.64 & -7.88 & -8.04 & -7.46 & -7.31 & -7.79 & -8.00 \\
\hline Cr I & -6.13 & -6.20 & -5.79 & -6.26 & -6.08 & -6.16 & -6.50 & -6.26 \\
\hline Cr II & -6.21 & -6.13 & -5.96 & -6.34 & -6.10 & -6.17 & -6.41 & -6.26 \\
\hline Mn I & $\ldots$ & $\ldots$ & $\ldots$ & -6.84 & -6.53 & -6.42 & -6.89 & -6.45 \\
\hline Mn II & -6.28 & -6.69 & -5.65 & -6.54 & -6.12 & -6.22 & -6.45 & -6.45 \\
\hline Fe I & -4.54 & -4.58 & -4.16 & -4.81 & -4.28 & -4.32 & -4.70 & -4.52 \\
\hline Fe II & -4.58 & -4.47 & -4.37 & -4.71 & -4.34 & -4.35 & -4.63 & -4.52 \\
\hline Co I & $\ldots$ & $\ldots$ & $\ldots$ & $\ldots$ & $\ldots$ & -6.54 & -6.67 & -7.08 \\
\hline $\mathrm{Ni} I$ & -5.82 & -5.67 & $\cdots$ & $\ldots$ & -5.10 & -5.31 & -5.71 & -5.75 \\
\hline Ni II & -5.87 & -5.67 & -5.64 & -5.91 & -5.00 & -5.00 & -5.48 & -5.75 \\
\hline Zn I & $\ldots$ & $\ldots$ & $\ldots$ & $\ldots$ & -6.00 & $\ldots$ & $\ldots$ & -7.40 \\
\hline $\mathrm{Sr}$ II & -8.79 & -8.77 & -9.12 & -9.52 & -8.35 & -8.01 & -8.30 & -9.10 \\
\hline Y II & $\ldots$ & $\ldots$ & -9.40 & $\ldots$ & -8.97 & -9.13 & -9.65 & -9.76 \\
\hline Zr II & -8.99 & -9.36 & -8.93 & $\ldots$ & -8.44 & -8.43 & -8.94 & -9.44 \\
\hline $\mathrm{Ba} I I$ & $\ldots$ & -9.29 & -9.69 & -10.07 & -8.62 & -8.49 & -9.29 & -9.87 \\
\hline$T_{\text {eff }}$ & 10325 & 10250 & 10135 & 10025 & 9600 & 9600 & 9500 & \\
\hline $\log g$ & 3.70 & 3.90 & 3.69 & 3.75 & 3.83 & 3.60 & 3.75 & \\
\hline$\xi(\mathrm{km} / \mathrm{s})$ & 0.3 & 0.0 & 1.8 & 0.0 & 2.5 & 1.8 & 1.6 & \\
\hline
\end{tabular}

the $\mathrm{S}$ and Mn overabundances. The discrepancies between the iron values derived from Fe I and Fe II lines can be reduced by making the star slightly cooler. The star appears to be slightly metal rich compared to the Sun and to the other superficially normal stars with effective temperatures near $10000 \mathrm{~K}$ in Table 7 (Adelman 1996 and references therein). This is consistent with the idea that 7 Sex might be the product of a binary having coalest.

New abundances have been derived from O I, Mg I, and P II lines found on the CASLEO spectrograms of $\mathrm{HR}$ 4817. The star is both $\mathrm{O}$ and $\mathrm{Mg}$ normal while being slightly $\mathrm{P}$ rich. Further the abundances from Mn I and II lines have been brought in better agreement.

The CASLEO spectrograms for 28 Her increase the number of lines analyzed relative to Adelman (1988). We now have an abunance of $\mathrm{O} I$ which suggests a slight deficiency. For the most part the changes in stellar parameters make the star slightly more metal rich.

\section{Final comments}

Table 8 compares the abundances of the HgMn stars with those from Adelman (1994) and shows that they fall within the general systematics. To see what correlations of abundance exist, we examined those which are available for all the stars in the table (He I, C II, Si II, Mg II, Si II, S II, Ca II, Ti II, Cr II, Mn II, Fe II, and Y II) with one another and with surface gravity and effective temperature. The correlation is regarded as significant if there is less than one chance in 20 that this value will occur by chance. For 14 items, the absolute value of $r$ must be greater than 0.532 (Bevington \& Robinson 1992). Those correlations with absolute $r$ values greater than this are given in Table 9. However, relative to Adelman's (1992, 1994) similar analyses with smaller number of $\mathrm{HgMn}$ stars, only the strongest correlations are found in common. Thus there is no question that the $\mathrm{He}, \mathrm{Mg}, \mathrm{Cr}$ abundances 
Table 8. Comparison of HgMn star abundances $(\log \mathrm{N} / \mathrm{H})$

\begin{tabular}{|c|c|c|c|c|c|c|c|c|c|c|c|c|c|c|c|}
\hline Species & HR 7361 & $\approx \mathrm{Cuc}$ & HR 8349 & HR 4817 & HR 7664 & $\pi^{1}$ Boo & $\mu$ Lep & $53 \mathrm{Tau}$ & $\nu$ Her & $\phi$ Her & HR 4072A & $28 \mathrm{Her}$ & HR. 7775 & $v \mathrm{Cnc}$ & Sun \\
\hline $\begin{array}{l}\mathrm{He} \text { I } \\
\mathrm{CI}\end{array}$ & -2.00 & -2.26 & -1.72 & -1.30 & .2 .10 & -1.72 & -1.57 & .1 .80 & $-1,82$ & -1.62 & $\begin{array}{l}-1.46 \\
-3.37\end{array}$ & -2.00 & -1.60 & -1.57 & $\begin{array}{l}(-1.01) \\
-3.34\end{array}$ \\
\hline C II & -3.89 & -3.97 & -3.64 & -3.84 & -3.88 & .3 .81 & -3.68 & .3 .95 & .4 .07 & -3.58 & -3.23 & -3.94 & -4.10 & -3.88 & $\begin{array}{l}-3.34 \\
-3.34\end{array}$ \\
\hline$\circ \mathrm{I}$ & $\begin{array}{r}-3.23 \\
-28 ?\end{array}$ & $\cdots$ & -250 & -3.03 & $\cdots$ & -3.43 & $\ldots$ & $\ldots$ & & $\ldots$ & $\ldots$ & -3.37 & -3.58 & $\ldots$ & -3.07 \\
\hline $\begin{array}{l}0 \text { II } \\
\text { Mg I }\end{array}$ & -2.82 & -5.17 & $\begin{array}{l}-2.69 \\
-5.27\end{array}$ & .451 & $\cdots$ & $\begin{array}{r}-2.76 \\
-5.20\end{array}$ & & $\cdots$ & & & & & 7 & 460 & -3.07 \\
\hline Mg II & -5.14 & -5.17 & -4.94 & $\begin{array}{l}-4.61 \\
-4.76\end{array}$ & -5.76 & $\begin{array}{l}-0.20 \\
-4.79\end{array}$ & $\begin{array}{r}.5 .17 \\
.4 .76\end{array}$ & $\begin{array}{c}\ldots \\
.4 .94\end{array}$ & $\begin{array}{l}-5.56 \\
-5.08\end{array}$ & $\begin{array}{l}-5.28 \\
-4.80\end{array}$ & $\begin{array}{l}-4.65 \\
-4.57\end{array}$ & $\begin{array}{l}-5.51 \\
-5.26\end{array}$ & $\begin{array}{l}-4.74 \\
-467\end{array}$ & -4.66 & $\begin{array}{r}-4.42 \\
-4.42\end{array}$ \\
\hline $\mathrm{Al} \mathrm{I}$ & & $\ldots$ & .6 .29 & $\ldots$ & 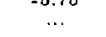 & $\begin{array}{c}-4.79 \\
\ldots\end{array}$ & $\begin{array}{c}-4.76 \\
\ldots\end{array}$ & $\begin{array}{c}-4.94 \\
\ldots\end{array}$ & $\begin{array}{c}-5.08 \\
\ldots\end{array}$ & $\begin{array}{c}-4.80 \\
\ldots\end{array}$ & $\begin{array}{l}-4.57 \\
-6.42\end{array}$ & $\begin{array}{c}-5.26 \\
\ldots\end{array}$ & $\begin{array}{l}-4.67 \\
-6.69\end{array}$ & $\begin{array}{l}-4.71 \\
-6.38\end{array}$ & $\begin{array}{l}-4.42 \\
-5.53\end{array}$ \\
\hline $\begin{array}{l}\text { Al II } \\
\text { Si I }\end{array}$ & & $\ldots$ & $\ldots$ & $\ldots$ & $\cdots$ & $\ldots$ & $\cdots$ & $\cdots$ & $\cdots$ & $\cdots$ & -6.85 & $\ldots$ & $\ldots$ & & .5 .53 \\
\hline Si II & -4.19 & -4.48 & -416 & -4.76 & -4.48 & .4 .31 & -4.29 & .4 .65 & $\ldots$ & $\dddot{m} .64$ & -4.53 & & & -4.78 & -4.45 \\
\hline Si III & -4.56 & -4.47 & -4.26 & -4.86 & .4 .80 & -4.47 & -4.22 & -4.59 & -4.85 & $\ldots$ & $\begin{array}{c}-4.53 \\
\ldots\end{array}$ & $\begin{array}{c}-4.78 \\
\quad . .\end{array}$ & $\begin{array}{c}-4.50 \\
\ldots\end{array}$ & $\begin{array}{c}-4.60 \\
\ldots\end{array}$ & $\begin{array}{l}-4.45 \\
-4.45\end{array}$ \\
\hline P II & -4.52 & .4 .73 & .4 .65 & .6 .25 & -4.99 & -5.66 & -5.41 & $\ldots$ & -5.82 & $\ldots$ & -5.54 & -5.60 & -5.59 & $\ldots$ & -6.55 \\
\hline P III & -4.45 & -4.77 & -4.88 & & & & & & & & & & & & -6.55 \\
\hline $\begin{array}{l}\mathrm{S} \text { II } \\
\mathrm{Ca} \text { I }\end{array}$ & -5.66 & -5.56 & .5 .08 & .5 .06 & .5 .48 & -5.24 & -4.68 & $\begin{array}{l}-5.34 \\
-5.34\end{array}$ & -5.29 & $\begin{array}{l}-4.91 \\
-6.20\end{array}$ & $\begin{array}{l}-4.64 \\
-5.24\end{array}$ & $\begin{array}{l}-4.35 \\
-6.11\end{array}$ & $\begin{array}{l}-4.72 \\
-5.24\end{array}$ & $\begin{array}{l}-5.05 \\
-6.21\end{array}$ & $\begin{array}{l}-4.79 \\
-5.64\end{array}$ \\
\hline $\mathrm{Ca}$ II & -4.93 & -6.67 & -4.06 & -6.36 & -5.55 & -5.17 & $\dddot{-0.27}$ & $\begin{array}{l}-6.34 \\
-5.02\end{array}$ & -5.83 & $\begin{array}{l}-0.20 \\
-5.36\end{array}$ & -4.80 & -5.51 & .5 .25 & -6.06 & -5.64 \\
\hline Sc II & -7.94 & -8.37 & -7.67 & -7.69 & -9.14 & -7.64 & -8.43 & -9.54 & -9.06 & -7.47 & -8.40 & & -9.65 & -8.19 & -8.90 \\
\hline Ti II & -6.83 & -6.82 & -6.86 & -5.50 & -6.20 & -6.75 & -6.41 & -6.76 & -6.26 & -6.37 & -6.16 & -6.82 & -6.08 & -6.38 & -7.01 \\
\hline V II & $\ldots$ & -7.60 & $\cdots$ & $\ldots$ & $\ldots$ & $\ldots$ & $<-7.44$ & & $\ldots$ & & -8.68 & & -8.18 & -8.20 & -8.00 \\
\hline Cr $\mathrm{t}$ & . & & 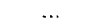 & 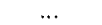 & & & & .6 .80 & 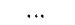 & .5 .18 & -5.69 & .5 .90 & -6.75 & -5.73 & -6.33 \\
\hline Cr II & -6.15 & .6 .42 & -6.11 & -5.40 & -6.70 & -5.69 & .5 .89 & -6.89 & -6.12 & .5 .50 & -5.62 & -6.16 & -5.72 & -5.88 & -6.33 \\
\hline Mn I & -3.97 & -4.39 & -4.28 & -3.97 & & -4.07 & -4.58 & -4.45 & .4 .70 & -4.92 & -5.51 & -5.62 & -5.83 & -6.21 & -6.61 \\
\hline Mn if & -4.10 & -4.45 & .4 .16 & .4 .04 & -6.42 & -4.18 & -4.45 & -4.68 & -4.88 & -5.08 & -6.38 & -5.48 & -5.84 & -5.84 & -6.61 \\
\hline $\mathrm{Fe} I$ & -4.23 & -4.49 & -4.65 & & -3.95 & -4.84 & -4.77 & .5 .28 & -4.76 & -4.35 & -4.00 & -4.37 & -4.12 & .4 .44 & .4 .52 \\
\hline Fe II & -4.41 & -4.57 & -4.46 & -4.87 & .3 .97 & -4.88 & -4.62 & -6.24 & -4.85 & -4.59 & -4.08 & -4.35 & -4.22 & .4 .60 & -4.52 \\
\hline$F=$ III & -4.26 & -4.44 & -4.22 & & -4.04 & -4.64 & -4.67 & -4.65 & -4.68 & -4.64 & .3 .97 & -4.32 & -4.08 & & -4.52 \\
\hline Ni I & & & & & & & & & & & & & & -5.58 & -5.75 \\
\hline Ni I [ & -6.21 & -6.18 & -6.11 & . & .6 .15 & .6 .77 & .6 .32 & -6.49 & -6.77 & .6 .26 & -6.62 & $\ldots$ & -6.60 & -5.62 & -5.75 \\
\hline Ga II & -4.81 & -4.75 & & -5.79 & -6.14 & -4.86 & -4.44 & -6.41 & -6.64 & -6.00 & & & -6.34 & & -9.12 \\
\hline St II & $-8.46:$ & -8.54 & -7.88 & & -8.75 & -6.84 & -7.32 & -8.17 & -8.10 & -8.34 & -6.49 & -6.62 & -6.48 & -8.01 & -9.10 \\
\hline Y II & -7.59 & -8.33 & -7.17 & -7.71 & -8.21 & -6.36 & -7.14 & -8.20 & -7.76 & -6.72 & -6.56 & -6.67 & -6.94 & -7.76 & .9 .76 \\
\hline $\mathrm{Zr} \mathrm{II}$ & & & -7.33 & $\cdots$ & 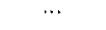 & $\cdots$ & $<-8.34$ & -7.49 & -8.95 & -7.32 & .8 .04 & .8 .53 & -8.73 & -7.60 & -9.40 \\
\hline Xe II & -5.22 & -5.60 & $\cdots$ & $\cdots$ & $\cdots$ & $\cdots$ & $\cdots$ & & & & & & & & $(-9.77)$ \\
\hline Ba II & 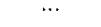 & $\ldots$ & $\cdots$ & $\cdots$ & $\cdots$ & $\cdots$ & $\cdots$ & $<-9.85$ & $\mathbf{- 8 . 8 5}$ & $<+8.06$ & -9.14 & $<-9.81$ & -9.70 & $<-6.97$ & -0.87 \\
\hline La II & $\ldots$ & $\ldots$ & $\ldots$ & $\ldots$ & $\ldots$ & $\ldots$ & $\ldots$ & $\ldots$ & $\ldots$ & $\ldots$ & -9.29 & $\ldots$ & & $\ldots$ & -10.78 \\
\hline Pr II & $\cdots$ & $\cdots$ & $\cdots$ & $\cdots$ & $\cdots$ & $\ldots$ & $\ldots$ & $\cdots$ & $\cdots$ & $\ldots$ & $\ldots$ & $\cdots$ & -7.72 & $\ldots$ & -11.29 \\
\hline Nd II & $\cdots$ & $\cdots$ & $\ldots$ & $\cdots$ & $\ldots$ & $\cdots$ & $\cdots$ & $\cdots$ & $\ldots$ & $\ldots$ & $\ldots$ & $\cdots$ & -7.82 & & -10.50 \\
\hline Gd II & $\cdots$ & $\cdots$ & -7.95 & $\cdots$ & $\cdots$ & $\ldots$ & $\cdots$ & $\cdots$ & $\ldots$ & $\cdots$ & $\ldots$ & $\cdots$ & -9.15 & -9.29 & -10.88 \\
\hline Ho II & $\cdots$ & $\cdots$ & $\cdots$ & $\cdots$ & $\cdots$ & $\cdots$ & $\cdots$ & $\cdots$ & $\ldots$ & $\ldots$ & $\cdots$ & $\cdots$ & -8.90 & $\ldots$ & -11.7 \\
\hline Tm II & $\cdots$ & $\cdots$ & $\cdots$ & $\ldots$ & $\ldots$ & $\ldots$ & $\ldots$ & $\ldots$ & $\ldots$ & $\ldots$ & $\ldots$ & $\cdots$ & -9.47 & $\ldots$ & -12.00 \\
\hline Pt I & $\ldots$ & $\cdots$ & & $\cdots$ & $\cdots$ & $\cdots$ & $\ldots$ & $\ldots$ & $\cdots$ & $\cdots$ & & 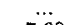 & -5.53 & $\ldots$ & -10.2 \\
\hline Pt II & $\cdots$ & $\ldots$ & -7.80 & $\ldots$ & $\ldots$ & $\ldots$ & $\ldots$ & $\cdots$ & $\ldots$ & $\cdots$ & -7.32 & -7.68 & $-7.23:$ & $\ldots$ & -10.2 \\
\hline Au II & $\cdots$ & $\cdots$ & $\ldots$ & $\cdots$ & $\cdots$ & $\ldots$ & $\ldots$ & $\cdots$ & $\cdots$ & $\cdots$ & $-7.34:$ & $\ldots$ & -7.18 & $\cdots$ & -10.99 \\
\hline $\mathrm{Hg} \mathrm{I}$ & 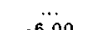 & $\ldots$ & $\cdots$ & $\ldots$ & $\ldots$ & $\ldots$ & -5.73 & $\ldots$ & -6.02 & $\begin{array}{l}-6.33 \\
.3 .3\end{array}$ & $\begin{array}{r}-5.67 \\
5.8\end{array}$ & $\dddot{m}$ & -5.90 & & $(-10.91)$ \\
\hline Hg II & -6.00 & -5.98 & -5.67 & $\ldots$ & -7.40 & -5.27 & .5 .65 & $\ldots$ & -5.76 & -6.38 & -5.83 & -7.80 & -6.06 & -7.80 & $(-10.91)$ \\
\hline $\mathbf{T}_{e f f}$ & 13300 & 13125 & 12975 & 12900 & 12876 & 12700 & 12400 & 12000 & 11900 & 11325 & 10900 & 10900 & 10650 & 10650 & \\
\hline $\log g$ & 3.75 & 3.59 & 3.90 & 3.72 & 3.51 & 4.02 & 3.91 & 4.21 & 3.74 & 3.79 & 4.07 & 3.96 & 4.13 & 4.13 & \\
\hline
\end{tabular}

correlate with one another and that the Mn abundance is a function of temperature. The $S$ and $Y$ abundances correlate with one another. But we should cautiously regard the other correlations.

Table 9. Definite Correlations

\begin{tabular}{lr}
\hline Compared Values & $r$ \\
\hline He I Mg II & 0.816 \\
He I Ti II & 0.567 \\
He I Cr II & 0.875 \\
C II Ca II & 0.535 \\
Mg II Cr II & 0.876 \\
Si II Ti II & -0.539 \\
S II Y II & 0.686 \\
S II $T_{\text {eff }}$ & -0.690 \\
Ca II log $g$ & 0.650 \\
Cr II Y II & 0.548 \\
Mn II $T_{\text {eff }}$ & 0.853 \\
Y II log $g$ & 0.533 \\
\hline
\end{tabular}

These studies showed that the CASLEO spectra have increased the quality of previous analyses. Further the CASLEO equivalent width scale is similar to those for
KPNO and DAO spectrograms. Our studies also indicate that for the HgMn stars there are probably a sufficient number of $\mathrm{Fe}$ II to determine the microturbulence using the region $4500-5000 \AA$. Thus elemental abundance analyses of such stars based solely on CASLEO spectrograms in the yellow are anticipated to produce good results.

Acknowledgements. The authors acknowledge use of the CCD and data reduction acquisition system supported by US NSF Grant AST 90-15827 to R.M. Rich. SJA thanks The Citadel Development Foundation for several grants which supported in part this collaboration. OIP is grateful to the staff of CASLEO for their assistance during the observing runs.

\section{References}

Adelman S.J., 1987, MNRAS 228, 573

Adelman S.J., 1988, MNRAS 235, 763

Adelman S.J., 1992, MNRAS 258, 167

Adelman S.J., 1994, MNRAS 266, 97

Adelman S.J., 1996, MNRAS 280, 130

Adelman S.J., Philip A.G.D., 1994, PASP 106, 1239

Adelman S.J., Philip A.G.D., 1996, MNRAS 252, 1181

Anders E., Grevesse N., 1989, Geochim. Cosmochim. Acta 53, 197

Bevington P.R., Robinson D.K., 1992, Data Reduction and Error Analysis for the Physical Sciences, 2nd edition. McGraw-Hill, New York 
Biemont E., Grevesse N., Hannaford P., Lowe R.M., 1981, ApJ 248,867

Fuhr J.R., Martin G.A., Wiese W.L., 1988, J. Phys. Chem. Ref. Data 15, Suppl. 4

Grevesse N., Biemont E., Hannaford P., Lowe R.M., 1981, Upper Main Sequence Stars, 23rd Liège Astrophys. Coll., p. 211

Gulliver A.F., Hill G., Adelman S.J., 1996, in Vienna Workshop on Stellar Atmospheres and Spectra Synthesis, Adelman S.J., Kupka F. and Wiess W.L. (eds.), ASP Conf. Ser. 108, 232

Hannaford P., Lowe R.M., Grevesse N., Biemont E., 1982, ApJ 261,736

Hauck B., Mermilliod M., 1990, A\&AS 86, 107

Hoffleit D., 1982, The Bright Star Catalogue, 4th edition, Yale University Observatory, New Haven

Hubeny I., Lanz T., Jeffery C.S., 1994, Daresbury Lab. New. Anal. Astron. Spectra 20, 30

Iglesias L., Velasco R., 1964, Publ. Inst. Opt. Madrid, No. 23

Isberg B., Litzen U., 1985, Phys. Scripta 31, 533

Johansson S., 1978, Phys. Scripta 18, 217

Kurucz R.L., 1979, ApJS 40, 1

Kurucz R.L., 1993, in Peculiar Versus Normal Phenomena in
A-type and Related Stars, Dworetsky M.M., Castelli F. and Faraggiana R. (eds.), ASP Conf. Ser. 44, 87

Kurucz R.L., Avrett E.H., 1981, Smithson. Astrophys. Obs. Spec. Rep. 381

Lanz T., Artru M.-C., 1985, Phys. Scripta 32, 155

Magnusson C.E., Zetterberg P.O., 1977, Phys. Scripta 15, 237

Martin G.A., Fuhr J.R., Wiese W.L., 1988, J. Phys. Chem. Ref. Data 15, Suppl. 3

Moore C.E., 1945, A Multiple Table of Astrophysical Interest, Princeton University Observatory, Princeton

Napiwotzki R., Schönberner D., Wenske V., 1993, A\&A 268, 653

Pintado O.I., Adelman S.J., 1996, A\&AS 118, 283

Reader J., Corliss C.H., 1980, NSRDS-NBS 68, Part 1, US Government Printing Office, Washington, DC

Svendenius N., Magnusson C.E., Zetterberg P.O., 1983, Phys. Scripta 27, 339

Wiese W.L., Martin G.A., 1980, NSRDS-NBS 68. Part 2, US Government Printing Office, Washington, DC

Wiese W.L., Smith M.W., Glennon B.M., 1966, NSRDS-NBS 4, US Government Printing, Office, Washington, DC

Wiese W.L., Smith M.W., Miles, B.M., 1969, NSRDS-NBS 22, US Government Printing Office, Washington, DC 
Table 3. The analysis of the metal lines of 7 Sex

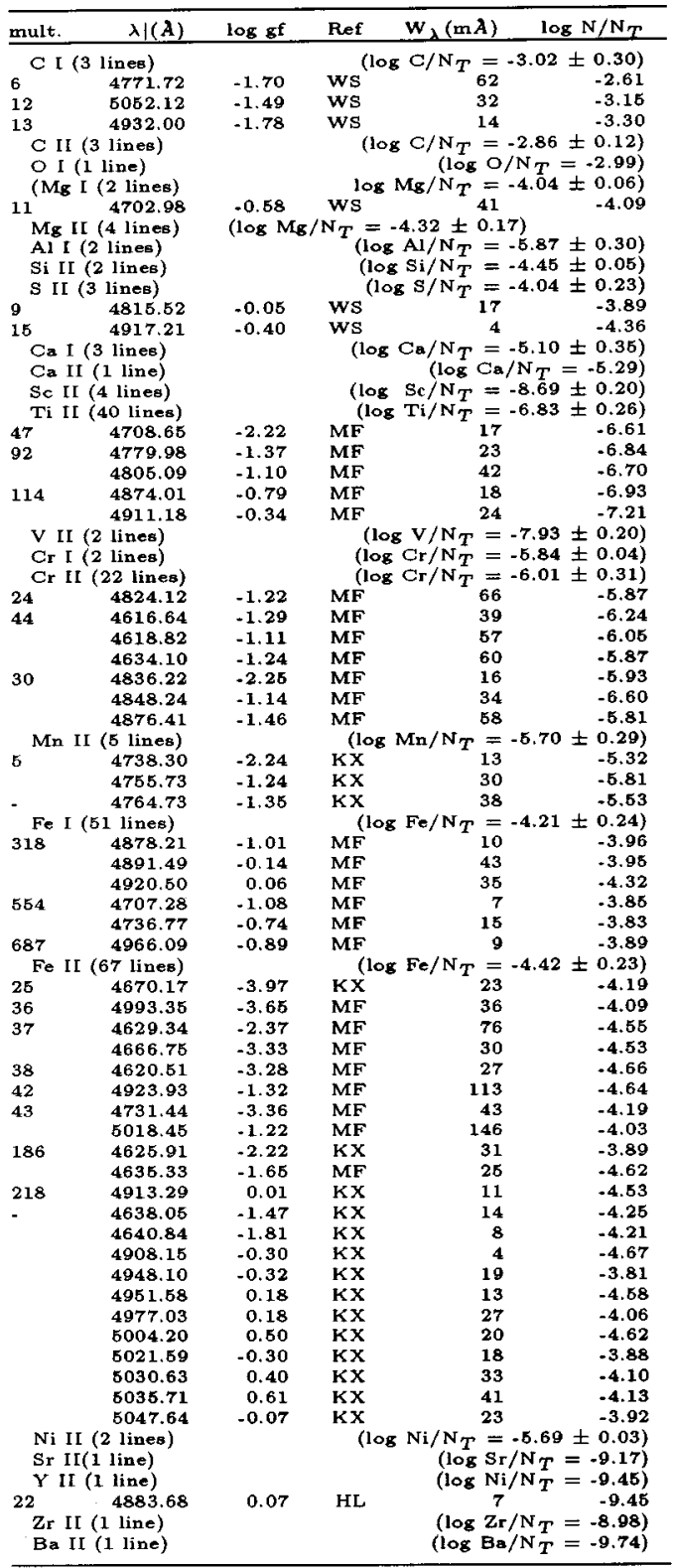

Table 4. The analysis of the metal lines of HR 4817

\begin{tabular}{|c|c|c|c|c|c|}
\hline mult. & $\lambda(A)$ & $\log g f$ & Ref & $w_{\lambda}(m A)$ & $\log N / N_{T}$ \\
\hline \multicolumn{2}{|c|}{ C II (3 lines) } & & \multicolumn{3}{|c|}{$\begin{array}{l}\left(\log \mathrm{C} / \mathrm{N}_{T}=-3.87 \pm 0.21\right) \\
(\log \mathrm{O} / \mathrm{N} T=-3.06 \pm 0.13)\end{array}$} \\
\hline $12^{\circ \mathrm{t}}$ & & & $W F^{(t}$ & & \\
\hline & $\begin{array}{l}5328.98 \\
5329.59\end{array}$ & -1.06 & WF & 13 & -3.23 \\
\hline \multirow{2}{*}{\multicolumn{2}{|c|}{ ( 2 lines) }} & -0.88 & \multirow{2}{*}{\multicolumn{3}{|c|}{$54 \pm 0.21)$}} \\
\hline 2 & & -0.28 & & & $\begin{array}{l}0.219 \\
-4.39\end{array}$ \\
\hline & 5183.60 & -0.16 & ws & 8 & .4 .68 \\
\hline \multicolumn{2}{|c|}{$\begin{array}{l}\text { Mg II (1 line) } \\
\text { Si II (1 lines) } \\
\text { Si III (1 lines) } \\
\text { P II }(1 \text { lines })\end{array}$} & & & $\begin{array}{c}(\log \mathrm{Mg} / \\
\log \mathrm{Si} \\
(\log \mathrm{Si}) \\
\mathrm{P} / \mathrm{N}_{T}=\end{array}$ & $\begin{array}{l}\left.\mathrm{N}_{T}=-4.79\right) \\
\left.\mathrm{N}_{T}=-4.79\right) \\
\left.\mathrm{N}_{T}=-4.89\right) \\
\left.\sigma_{T .28} \pm 0.30\right)\end{array}$ \\
\hline $10^{\circ}$ & $\begin{array}{l}\text { nines) } \\
5425.88\end{array}$ & 0.19 & $\mathrm{ws}^{2}$ & 5 & -6.69 \\
\hline & 5263.47 & 0.33 & ws & 13 & $\begin{array}{r}-5.96 \\
-6.20\end{array}$ \\
\hline${ }^{15}$ SII & $\begin{array}{l}4602.08 \\
\text { lines) }\end{array}$ & 0.74 & ws & $\mathrm{S}_{T} \stackrel{6}{=}$ & $.09 \pm \begin{array}{c}-6.20 \\
0.30)\end{array}$ \\
\hline & 5432.82 & 0.21 & ws & 12 & $\begin{array}{l}-5.11 \\
-5.37\end{array}$ \\
\hline & $\begin{array}{l}5454.38 \\
\text { line) }\end{array}$ & 0.44 & & $(\log \mathrm{Ca}$ & $\left.N_{T}=-5.39\right\}$ \\
\hline & $\begin{array}{l}\text { line) } \\
4 \text { lines) }\end{array}$ & & & $\begin{array}{c}(\log \mathrm{Sc} / \\
\mathrm{Ti} / \mathrm{N}_{T}=\end{array}$ & $\begin{array}{l}\left.N_{T}=-7.72\right) \\
5.53 \pm 0.32\end{array}$ \\
\hline 17 & $\begin{array}{l}4 \text { lines) } \\
4762.78\end{array}$ & -2.71 & $\mathrm{MF}$ & $11 / N_{19}$ & -4.87 \\
\hline 69 & 5336.78 & -1.70 & MF & 37 & -5.10 \\
\hline 70 & 5381.01 & -2.08 & MF & 7 & -5.84 \\
\hline 70 & 5188.69 & .1 .21 & MF & 20 & -6.09 \\
\hline & 5226.53 & -1.30 & MF & 57 & $\begin{array}{r}-4.93 \\
-5.63\end{array}$ \\
\hline & $\begin{array}{l}5185.90 \\
5072.28\end{array}$ & $\begin{array}{l}-1.35 \\
-0.75\end{array}$ & ${ }_{\mathrm{KX}}^{\mathrm{MF}}$ & $\begin{array}{l}26 \\
13\end{array}$ & $\begin{array}{l}-5.63 \\
.6 .10\end{array}$ \\
\hline & $\begin{array}{l}8072.28 \\
3 \text { lines) }\end{array}$ & & (loc & $\left\langle\mathbf{N}_{T}=\right.$ & $0.32)$ \\
\hline 23 & 8346.54 & -2.95 & $\mathrm{Kx}$ & 10 & -4.92 \\
\hline 43 & $\begin{array}{l}5407.60 \\
5532.50\end{array}$ & $\begin{array}{l}-2.09 \\
-2.09\end{array}$ & $\mathrm{KX}$ & 7 & $\begin{array}{l}-5.92 \\
-5.54\end{array}$ \\
\hline 43 & $\begin{array}{l}5232.060 \\
\end{array}$ & $\begin{array}{l}-2.09 \\
-1.16\end{array}$ & 角 & 40 & $\begin{array}{l}-0.04 \\
-5.52\end{array}$ \\
\hline & 5274 & -129 & ${ }_{K X}^{M r}$ & 27 & $\begin{array}{l}-5.78 \\
\end{array}$ \\
\hline & 5308.44 & 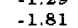 & $\mathrm{MF}$ & 19 & -5.53 \\
\hline & 5334.88 & .1 .56 & $\mathrm{Kx}$ & 14 & -5.93 \\
\hline 44 & 4616.64 & -1.29 & $\mathrm{MF}$ & 29 & -5.76 \\
\hline & 4618.82 & $\begin{array}{l}-1.11 \\
-1.24\end{array}$ & MF & $\begin{array}{l}51 \\
39\end{array}$ & $\begin{array}{l}-5.28 \\
-5.50\end{array}$ \\
\hline 50 & $\begin{array}{l}46334.10 \\
5502.07\end{array}$ & $\begin{array}{l}-1.24 \\
-1.99\end{array}$ & $\begin{array}{l}\mathrm{MF} \\
\mathrm{MF}\end{array}$ & $\begin{array}{l}39 \\
12\end{array}$ & $\begin{array}{l}-5.60 \\
-5.56\end{array}$ \\
\hline & 5503.21 & -2.31 & $\mathrm{KX}$ & & -5.44 \\
\hline $\mathrm{Mn}$ & $\begin{array}{l}\text { lines) } \\
(2) \text { (ines) }\end{array}$ & $(\log \mathrm{M}$ & $\mathrm{N}_{T_{1 / 0}}=$ & $\begin{array}{l}=0.03 \\
=\end{array}$ & $0.33)$ \\
\hline & 42 lines) & -1.86 & $\mathrm{kx}$ & 20 & \\
\hline & $\begin{array}{l}4717.26 \\
47784\end{array}$ & -2.02 & $\hat{K} \hat{x}$ & 56 & $\begin{array}{l}-4.08 \\
-3.57\end{array}$ \\
\hline & 4730.40 & -2.15 & $\mathrm{KX}$ & 48 & $\begin{array}{l}-3.04 \\
-3.72\end{array}$ \\
\hline & 4742.95 & -2.98 & $\mathrm{KX}$ & 23 & -3.68 \\
\hline & 4749.11 & -2.00 & $\mathrm{KX}$ & 14 & -4.61 \\
\hline & 4764.73 & -1.35 & $\mathrm{kx}$ & 79 & $\begin{array}{r}-3.50 \\
-368\end{array}$ \\
\hline & 5102.52 & -1.93 & $K x$ & 47 & $\begin{array}{l}-3.68 \\
-3.80\end{array}$ \\
\hline & $\begin{array}{l}5107.09 \\
5133.33\end{array}$ & $\begin{array}{l}-1.48 \\
-1.88\end{array}$ & $\begin{array}{l}K X \\
K X\end{array}$ & $\begin{array}{l}37 \\
32\end{array}$ & $\begin{array}{l}-3.80 \\
-4.20\end{array}$ \\
\hline & 52943 & $\begin{array}{l}-1.00 \\
-0.04\end{array}$ & $K_{K X}^{K X}$ & $\begin{array}{l}32 \\
41\end{array}$ & $\begin{array}{l}-4.20 \\
-3.95\end{array}$ \\
\hline & & 0.66 & $\mathrm{KX}$ & 67 & $\begin{array}{l}-3.80 \\
-3.86\end{array}$ \\
\hline & & 0.83 & $\mathrm{KX}$ & 69 & -3.98 \\
\hline & 5299.30 & 0.40 & $\mathrm{kX}$ & 65 & -3.94 \\
\hline & & -2.07 & $\mathrm{kx}$ & 10 & $\begin{array}{r}-4.30 \\
-3.63\end{array}$ \\
\hline & ${ }^{533}$ & -0.15 & $\mathrm{kx}$ & 18 & $\begin{array}{r}-3.63 \\
-4.23\end{array}$ \\
\hline & $\begin{array}{l}5421.92 \\
5507\end{array}$ & -2.18 & $\begin{array}{l}\mathrm{k} \\
\mathrm{K}\end{array}$ & 17 & $\begin{array}{l}-4.23 \\
-4.57\end{array}$ \\
\hline & & -1.32 & $\mathrm{KX}$ & 44 & $\begin{array}{l}-4.07 \\
-4.24\end{array}$ \\
\hline & 5570 & -1.44 & $\mathrm{KX}$ & 53 & .3 .81 \\
\hline & & -1.40 & $\mathrm{KX}$ & 62 & -3.54 \\
\hline & 5 lines) & & $x$ & 6 & $\begin{array}{l}0.26) \\
-4.43\end{array}$ \\
\hline 37 & $\begin{array}{l}4670.17 \\
4629.34\end{array}$ & & $\mathrm{MF}$ & 28 & -5.02 \\
\hline 41 & 5284.10 & -3.19 & MF & 12 & -4.71 \\
\hline 42 & 5018.45 & & & 60 & -5.07 \\
\hline 43 & 4656.87 & -3.63 & $F$ & 9 & $\begin{array}{r}-4.42 \\
-4.63\end{array}$ \\
\hline 49 & $\begin{array}{l}4731.44 \\
5334.62\end{array}$ & $\begin{array}{l}-3.36 \\
-2.05\end{array}$ & & 31 & $\begin{array}{l}-4.63 \\
-5.03\end{array}$ \\
\hline & & -1.94 & $M$ & 34 & $\begin{array}{l}-0.03 \\
-5.08\end{array}$ \\
\hline$D b$ & & 0 & & 23 & -4.38 \\
\hline $\operatorname{sen}^{2}$ & & 0.12 & & 9 & -4.66 \\
\hline 186 & & -2.22 & $\mathrm{kx}$ & 2 & -5.09 \\
\hline & & -1.65 & & 14 & -4.76 \\
\hline 205 & & 0.11 & & 11 & $\begin{array}{l}-4.67 \\
-4.58\end{array}$ \\
\hline & & $\begin{array}{l}-1.84 \\
-0.02\end{array}$ & $k$ & 16 & -4.34 \\
\hline & & & & 31 & -4.25 \\
\hline & & 0.61 & & 17 & -4.93 \\
\hline & & & & 15 & -4.32 \\
\hline & & 0.24 & & 11 & -4.82 \\
\hline & & & & 13 & -4.76 \\
\hline & & -0.19 & & 10 & $\begin{array}{r}-4.46 \\
\end{array}$ \\
\hline & & & & 12 & $=4.40$ \\
\hline & & & & 18 & -5.00 \\
\hline & & -3. & & 7 & -4.80 \\
\hline & & 1. & KX & 21 & -5.15 \\
\hline & & 0. & & 9 & -5.19 \\
\hline & & & & 27 & $\begin{array}{r}-4.38 \\
\end{array}$ \\
\hline & & & & 21 & -4.67 \\
\hline & & & & 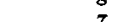 & -0.144 \\
\hline & & & & 16 & -4.72 \\
\hline & & & & 7 & -5.12 \\
\hline & & & & 8 & .5 .02 \\
\hline & & 0.36 & $\mathrm{kx}$ & 12 & -4.74 \\
\hline & 20 & & $\mathrm{MF}$ & 16 & $\begin{array}{c}-5.20 \\
0.07)\end{array}$ \\
\hline & & & & (log 17 & $-7.74)$ \\
\hline
\end{tabular}


Table 5. The analysis of the metal lines of $\mu$ Lep

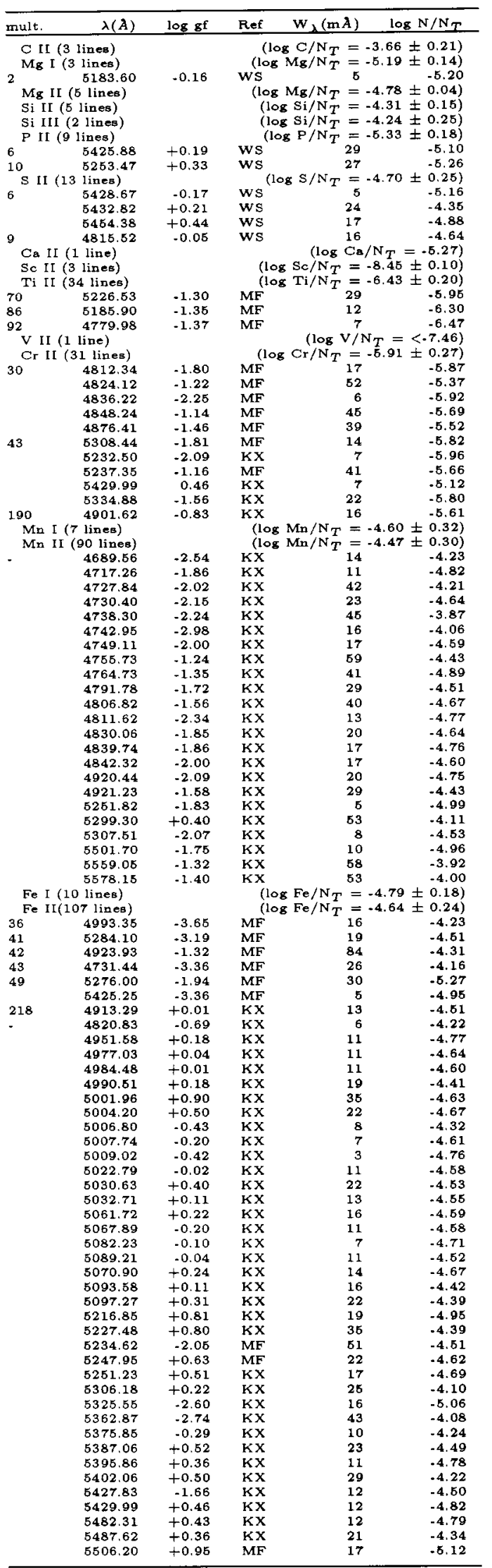

Table 5. continued

\begin{tabular}{|c|c|c|c|c|c|}
\hline mult. & $\lambda(A)$ & $\log g f$ & Ref & $w_{\lambda}(m \cdot \dot{A})$ & $\log N / N_{T}$ \\
\hline \multirow{2}{*}{\multicolumn{2}{|c|}{$\begin{array}{l}\text { Fe III (1 line) } \\
\text { Ni II (1 line) } \\
\text { Ga II (2 lines) } \\
\text { Sr II (3 lines) } \\
\text { YII (17 lines) } \\
20 \quad 5205.73\end{array}$}} & & \multicolumn{3}{|c|}{$\begin{array}{r}\left(\log \mathrm{Fe} / \mathrm{N}_{T}=-4.69\right) \\
\left(\log N \mathrm{Ni} / \mathrm{N}_{T}=-6.34\right) \\
\left(\log \mathrm{Ga} / \mathrm{N}_{T}=-4.46 \pm 0.46\right) \\
\left(\log \mathrm{Sr}_{T}=-7.34 \pm 0.17\right) \\
\left(\log \mathrm{N} / \mathrm{N}_{T}=-7.14 \pm 0.24\right)\end{array}$} \\
\hline & & -0.34 & & $Y / N_{T}=$ & \\
\hline & 4823.30 & & & 10 & \\
\hline & 4883.68 & +0.07 & $\mathrm{HL}$ & 48 & -6.44 \\
\hline & $\begin{array}{l}4854.86 \\
-10012\end{array}$ & -0.38 & $\mathrm{HL}$ & 12 & -7.48 \\
\hline \multirow{3}{*}{\multicolumn{2}{|c|}{$\begin{array}{l}\mathrm{ZrII} \text { (1 line) } \\
\mathrm{Hg} \mathrm{I}(2 \text { line) } \\
\mathrm{S}\end{array}$}} & & \multirow{2}{*}{\multicolumn{3}{|c|}{ 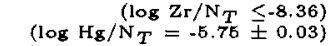 }} \\
\hline & & +0.45 & & & \\
\hline & & & & & \\
\hline
\end{tabular}


Table 6. The analysis of the metal lines of $28 \mathrm{Her}$

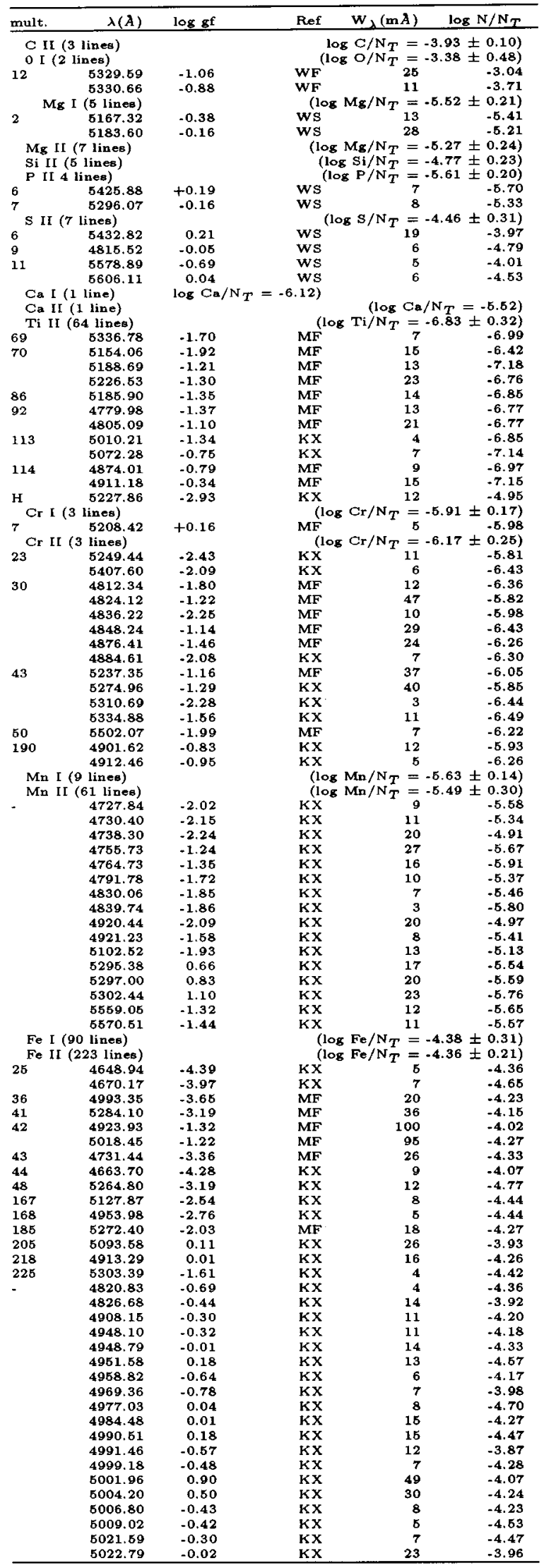

Table 6. continued

\begin{tabular}{|c|c|c|c|c|c|}
\hline mult & $\lambda(A)$ & $\log g^{f}$ & Ref & $w_{\lambda}(m A)$ & $\log \mathrm{N}_{\mathrm{N}} \mathrm{N}_{T}$ \\
\hline & 5026.81 & .0 .22 & $\mathrm{Kx}$ & 9 & -4.36 \\
\hline & 5030.63 & 0.40 & $k x$ & 32 & $-4,05$ \\
\hline & $\begin{array}{l}5035.71 \\
5045.11\end{array}$ & $\begin{array}{r}0.61 \\
.0 .13\end{array}$ & $\begin{array}{l}K X \\
K x\end{array}$ & $\begin{array}{r}30 \\
8\end{array}$ & $\begin{array}{l}-4.35 \\
-4.52 \\
\end{array}$ \\
\hline & $\begin{array}{l}5046.11 \\
5047.64\end{array}$ & $\begin{array}{l}-0.13 \\
-0.07\end{array}$ & Kx & 12 & .4 .33 \\
\hline & 5060.26 & $\begin{array}{l}-0.52 \\
-0.52\end{array}$ & $\mathbf{K x}$ & 6 & -4.24 \\
\hline & 5061.72 & 0.22 & $\hat{K X}$ & 23 & -4.18 \\
\hline & 5067.89 & .0 .20 & $\mathrm{kx}$ & 10 & -4.30 \\
\hline & 8070.90 & 0.24 & $k x$ & 23 & -4.18 \\
\hline & 5074.05 & $\begin{array}{r}-1.97 \\
0.28\end{array}$ & $\begin{array}{ll}K X \\
K x\end{array}$ & $\begin{array}{r}7 \\
13\end{array}$ & $\begin{array}{l}-4.60 \\
-4.55\end{array}$ \\
\hline & $\begin{array}{l}5075.76 \\
5082.23\end{array}$ & $\begin{array}{r}0.28 \\
-0.10\end{array}$ & $\begin{array}{l}K X \\
k x\end{array}$ & $\begin{array}{l}13 \\
12\end{array}$ & $\begin{array}{l}-4.00 \\
-4.28\end{array}$ \\
\hline & 5089.1 & -0.04 & $\mathrm{kx}$ & 18 & .4 .11 \\
\hline & 5086.31 & $\begin{array}{l}-0.048 \\
-0.48\end{array}$ & $\hat{k} \hat{x}$ & 6 & .4 .28 \\
\hline & 5097.27 & 0.31 & $\mathrm{kx}$ & 26 & -4.12 \\
\hline & 5106.11 & .0 .19 & $\mathrm{kx}$ & 8 & -4.45 \\
\hline & 5112.99 & -0.50 & $\mathrm{Kx}$ & 11 & -3.95 \\
\hline & $\begin{array}{l}5117,01 \\
5143.88\end{array}$ & $\begin{array}{l}-0.13 \\
0.10\end{array}$ & $\begin{array}{l}K x \\
K x\end{array}$ & $\begin{array}{r}6 \\
23\end{array}$ & $\begin{array}{l}-4.61 \\
-3.98 \\
\end{array}$ \\
\hline & $\begin{array}{l}5143.88 \\
5144.36\end{array}$ & $\begin{array}{l}0.10 \\
0.28\end{array}$ & ${ }_{K X}^{K X}$ & $\begin{array}{l}23 \\
11\end{array}$ & $\begin{array}{l}-3.86 \\
-4.66\end{array}$ \\
\hline & $\begin{array}{l}5144.36 \\
5145.78\end{array}$ & $\begin{array}{l}0.03 \\
0.03\end{array}$ & $\mathrm{KX}$ & 9 & -4.55 \\
\hline & 5148.94 & .0 .40 & $\mathrm{KX}$ & 7 & -4.30 \\
\hline & $\begin{array}{l}0140.84 \\
6160.85\end{array}$ & -2.64 & KX & 8 & -4.36 \\
\hline & 8166.56 & -0.03 & $\mathrm{KX}$ & 9 & -4.46 \\
\hline & 5169.00 & -0.87 & $\mathrm{MF}$ & 88 & $\begin{array}{r}-4.82 \\
-4.00\end{array}$ \\
\hline & $\begin{array}{r}5175.40 \\
5177.02\end{array}$ & $\begin{array}{l}-2.27 \\
-0.18\end{array}$ & $\begin{array}{l}k \times \\
k \times \\
k \times\end{array}$ & $\begin{array}{l}4 \\
5\end{array}$ & $\begin{array}{l}-4.00 \\
-4.65 \\
\end{array}$ \\
\hline & 5178.37 & $\begin{array}{l}-0.18 \\
.0 .59\end{array}$ & $\begin{array}{l}\mathrm{kx} \\
\mathrm{kx}\end{array}$ & 10 & $\begin{array}{l}.4 .80 \\
.3 .87\end{array}$ \\
\hline & 5180,31 & $\begin{array}{l}0.009 \\
0.04\end{array}$ & $K x$ & 8 & -.4 .64 \\
\hline & 5186.87 & .0 .30 & $\mathrm{Kx}$ & 7 & -4.33 \\
\hline & 5197.56 & .2 .10 & $\mathrm{KX}$ & 40 & -4.94 \\
\hline & 5199.12 & 0.10 & $\mathrm{KX}$ & 20 & -4.09 \\
\hline & 5203.64 & .0 .05 & $k \times$ & 10 & -4.40 \\
\hline & $\begin{array}{r}5213.99 \\
5215.34\end{array}$ & -0.22 & $\begin{array}{l}k x \\
k x \\
x\end{array}$ & 9 & $\begin{array}{l}-4.26 \\
-4.50\end{array}$ \\
\hline & $\begin{array}{l}5216.34 \\
5216.85\end{array}$ & $\begin{array}{r}.0 .01 \\
0.81\end{array}$ & KX & 20 & $\begin{array}{l}-4.50 \\
-4.75\end{array}$ \\
\hline & 5223.26 & .0 .41 & $\mathrm{kx}$ & 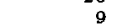 & -4.08 \\
\hline & 5223.80 & $\begin{array}{l}-0.59 \\
-.49\end{array}$ & $\mathrm{Kx}$ & 8 & -4.03 \\
\hline & 5225.98 & -0.40 & $\mathrm{Kx}$ & 13 & -3.92 \\
\hline & 5234.62 & -2.05 & $\mathrm{MF}$ & 68 & -4.08 \\
\hline & 5239.81 & $\begin{array}{l}-0.46 \\
0.63\end{array}$ & $k x$ & 92 & $\begin{array}{r}-4.03 \\
-4.38\end{array}$ \\
\hline & $\begin{array}{l}5247.95 \\
5254.93\end{array}$ & $\begin{array}{r}0.63 \\
-3.23\end{array}$ & $\begin{array}{l}\mathrm{kX} \\
\mathrm{KX}\end{array}$ & 20 & $\begin{array}{l}-4.58 \\
-4.43\end{array}$ \\
\hline & $\begin{array}{l}5264.93 \\
5251.23\end{array}$ & $\begin{array}{r}-3.23 \\
0.51\end{array}$ & KX & 26 & -4.22 \\
\hline & 5257.90 & .0 .71 & $\mathrm{kx}$ & 7 & -3.90 \\
\hline & 5260.26 & 1.07 & $\mathrm{Kx}$ & 30 & -4.67 \\
\hline & 5264.81 & -3.19 & MF & 38 & -3.91 \\
\hline & 5270.03 & 0.07 & $\mathrm{Kx}$ & 14 & -4.26 \\
\hline & 5291.67 & 0.58 & $k x$ & 27 & -4.25 \\
\hline & $\begin{array}{l}5306.18 \\
5318\end{array}$ & 0.22 & 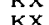 & 21 & $\begin{array}{r}-4.10 \\
.4 .49\end{array}$ \\
\hline & 531875 & -0.57 & $\mathrm{~K} \times$ & 7 & .408 \\
\hline & 5322.23 & .0 .52 & $k x$ & 4 & -4.36 \\
\hline & 5339.58 & 0.54 & $k x$ & 22 & -4.41 \\
\hline & 5375.85 & -0.29 & $K x$ & 11 & -4.04 \\
\hline & 5387.06 & 0.52 & $k \mathrm{X}$ & 23 & -4.29 \\
\hline & $\begin{array}{l}5395.86 \\
5402.06\end{array}$ & $\begin{array}{l}0.36 \\
0.50\end{array}$ & $\begin{array}{l}K X \\
K x\end{array}$ & $\begin{array}{l}12 \\
23\end{array}$ & $\begin{array}{l}-4.55 \\
-4.26\end{array}$ \\
\hline & 5408.81 & -2.39 & $\mathrm{Kx}$ & 7 & .4 .45 \\
\hline & 5411.36 & -0.44 & $k x$ & 7 & -4.06 \\
\hline & 5414.05 & $\begin{array}{r}-3.79 \\
\end{array}$ & $\mathrm{MF}$ & 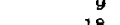 & -4.34 \\
\hline & $\begin{array}{l}5425.25 \\
5427.83\end{array}$ & $\begin{array}{l}-3.36 \\
-1.66\end{array}$ & $\mathrm{MP}$ & $\begin{array}{l}18 \\
18\end{array}$ & $\begin{array}{l}-4.23 \\
-4.23\end{array}$ \\
\hline & 5429.99 & 0.46 & $\mathrm{Kx}$ & 19 & -4.35 \\
\hline & 5442.35 & -0.30 & $\mathrm{kx}$ & 8 & -4.16 \\
\hline & 5443.45 & -0.59 & $k x$ & 4 & -4.22 \\
\hline & 5444.39 & -0.18 & $k x$ & 10 & .4 .12 \\
\hline & 5445,81 & $\begin{array}{r}-0.11 \\
-0.3\end{array}$ & KX & 8 & $\begin{array}{r}.4 .38 \\
4.92\end{array}$ \\
\hline & 545503 & -0.03 & $\mathrm{Kx}$ & 9 & $\begin{array}{l}-4.02 \\
-3.94\end{array}$ \\
\hline & 546503 & 0.52 & $\mathrm{Kx}$ & 15 & -4.57 \\
\hline & 546691 & -1.88 & $k x$ & 20 & -3.88 \\
\hline & 5475.83 & -0.18 & $\mathrm{kx}$ & 8 & -4.28 \\
\hline & 5479.41 & -0.42 & $k x$ & 6 & -4.24 \\
\hline & 5 & 0.43 & $k x$ & 18 & -4.37 \\
\hline & 5487.62 & 0.36 & $k x$ & 28 & -3.90 \\
\hline & ${ }_{55}$ & -0.14 & $\kappa$ & & -4.422 \\
\hline & 5503.21 & 0.95 & $M F$ & 26 & .4 .61 \\
\hline & $\begin{array}{l}5506.20 \\
5510.78\end{array}$ & 0.00 & $\mathrm{Kx}$ & 11 & $\begin{array}{r}-4.29 \\
\end{array}$ \\
\hline & 5529.05 & .0 .25 & $\mathrm{kx}$ & 5 & -4.45 \\
\hline & 5534.83 & .2 .93 & MF & 41 & -4.06 \\
\hline & 55 & .0 .51 & $\mathrm{KX}$ & 5 & -4.14 \\
\hline & 35 & -0.23 & $k x$ & ${ }^{4}$ & $\begin{aligned}-4.62 \\
\end{aligned}$ \\
\hline & 5867.84 & - $\begin{array}{l}-1,89 \\
09\end{array}$ & $\begin{array}{l}k x \\
k x \\
k x\end{array}$ & 15 & $\begin{array}{r}-4.23 \\
-4.14\end{array}$ \\
\hline & 5588.22 & & & 10 & $\begin{array}{l}-4.14 \\
-4.32)\end{array}$ \\
\hline & & & & & $0.09)$ \\
\hline & 32 lines) & & & & $0.25)$ \\
\hline 12 & 4682.32 & -1.51 & $\mathrm{HL}$ & 20 & -7.11 \\
\hline & 8 & -1.29 & HL & 40 & $\begin{array}{r}-6.25 \\
6.70\end{array}$ \\
\hline & & -1.28 & HL & $\begin{array}{l}28 \\
34\end{array}$ & $\begin{array}{l}-6.70 \\
-6.44\end{array}$ \\
\hline & & -1. & t & 4i & $\begin{array}{l}-0.444 \\
-6966\end{array}$ \\
\hline 27 & 1 & -0 & $\begin{array}{lll}L \\
L\end{array}$ & 39 & .6 .20 \\
\hline & 5497.41 & .0. & $\mathrm{HL}$ & 38 & -6.63 \\
\hline & 5544.61 & $-1,09$ & $\mathrm{HL}$ & 25 & -6.63 \\
\hline & 5196.42 & -0.88 & & 14 & -7.23 \\
\hline & $\begin{array}{l}10 \text { lines }) \\
(1 \text { line) }\end{array}$ & & & $\begin{array}{ll}\mathrm{Zr} r \mathrm{~N}_{T}= \\
\left(\log _{\mathrm{Ba}}\right)\end{array}$ & $\begin{array}{l}=0.15) \\
=-9.82)\end{array}$ \\
\hline & $(8$ lines) & & & $t / \mathbf{N}_{T}=$ & $9 \pm 0.76)$ \\
\hline & (1 line) & & & $(\log \mathrm{Hg} /$ & $\left.T_{T}=-7.81\right)$ \\
\hline
\end{tabular}

